\title{
The COVID-19 Pandemic: Role of Coping Humor and Internal Health Locus of Control on Social Dysfunction and Anxiety \& Depression
}

\author{
Muhammad Arief Sumantri ${ }^{1,2 *}$, Zahrani ${ }^{1}$, Hilda Rosa Ainiyah'1, Azmul Fuady Idham ${ }^{1,2}$
}

${ }^{1}$ Research Team, Intellectual Freedom (Ruang Ide), Indonesia, ${ }^{2}$ Research Team, Halo Jiwa Indonesia, Indonesia

\begin{abstract}
The concerns about the impact of social distancing on mental health have been widely discussed. This study aimed to know the predictive effect of coping humor and Internal Health Locus of Control (Internal HLOC) on social dysfunction and anxiety \& depression during the implementation of the COVID-19 social distancing agenda. This study was also intended to assess the effect of humor content on coping humor. A quantitative approach was used as the method of the study with 243 online-recruited participants, and a PLS-SEM analysis was applied to find out the predictive effect in this study. The results and conclusions showed that anxiety $\&$ depression predict social dysfunction $\left(\beta=0.584\right.$, $t$-value $\left.=11.93, f^{2}=0.563\right)$. It was found that coping humor was able to directly increase the Internal HLoC $\left(\beta=0.187\right.$, t-value $\left.=2.60, \mathrm{f}^{2}=0.036\right)$ and indirectly decrease social dysfunction $(\beta=-0.144, \mathrm{t}$-value $=2.85)$ and anxiety \& depression $(\beta=-0.070$, t-value $=2.42)$. Humor content unrelated to the issue of COVID-19 directly increase the coping-humor level $(\beta=0.266, t-v a l u e=4.13$, $\left.f^{2}=0.076\right)$, and indirectly increase Internal HLoC $(\beta=0.050$, t-value $=2.07)$, and decrease anxiety \& depression level $(\beta=-0.046$, t-value $=2.20)$. On the other hand, Internal HLoC directly decrease levels of social dysfunction $\left(\beta=-0.233\right.$, t-value $\left.=4.126, f^{2}=0.089\right)$ and anxiety \& depression $(\beta=-0.373$, t-value $\left.=7.84, f^{2}=0.161\right)$.
\end{abstract}

Keywords: coping humor, depression, locus of control, social distancing, social dysfunction

\section{Introduction}

The President's speech on Sunday, March 15, 2020, at Bogor Palace, 1 has become a signal for the implementation of social distancing agenda in Indonesia to prevent the spreading of the coronavirus disease 2019 (COVID-19). Social distancing has been widely applied not only in Indonesia but also in many other countries. Even the use of the term "social distancing" was responded to by the World Health Organization (WHO), where WHO suggested using the term "physical distancing" because it refers explicitly to the restrictions of physical contact, not social contact. ${ }^{1}$ However, regardless of the term used, the advantages and effectiveness are believed to exist in the practice of social distancing. Also, worries about its impact on mental health have surfaced. Social distancing is strongly suspected to be the potential cause of stress, panic, anxiety, and depression, especially in individuals with history of anxiety disorder, compulsive disorder, or paranoia. $^{2}$

The study from Sibley, et al., ${ }^{3}$ in New Zealand

Correspondence*: Muhammad Arief Sumantri, Research Team, Intellectual Freedom (Ruang Ide), Bebekan Timur No. 43, East Java, Indonesia 61257, Email: aripsumantri142@gmail.com, Phone: +6287853941215 revealed that the participants in lockdown (surveyed during pandemics) had higher mental stress levels than participants in pre-lockdown (surveyed before the pandemic status was established). People have shown more stressful experiences concerning health problems and job insecurities, work-family conflicts, and even discrimination during the pandemic. ${ }^{4-6}$ Furthermore, Zacher \& Rudolph, ${ }^{7}$ in Germany, conducted a study at the early stage of pandemic (December 2019-May 2020) and showed that the COVID-19 pandemic has not only an impact on medical and economic crises but also psychological dimensions; the main aspects of society on subjective well-being have been decreased. This matter needs further scientific research to provide additional literature about physical/social distancing when applied to pandemic situations.

Anxiety and depression are highlighted by a series of remembered and believed negativity, affecting someone's social function. Social factors, social disorder, and impaired social function are often associated with depression. ${ }^{8}$ Social disorders have also been proved to

Received : February 8, 2021

Accepted : July 5, 2021

Published: November 29, 2021 
be positively correlated with anxiety symptoms. ${ }^{9}$ Close relationships (with spouses, families, or colleagues) and superficial interactions as the elements that support social function are also associated with humor. ${ }^{10-12}$ In cross-cultural studies, it has been proved that subjects with a high level of humor show a higher level of wellbeing and lower level of anxiety, depression, or negative emotions. ${ }^{13-15}$ Many studies also underlined that humor has a positive effect on social, emotional, and physical well-being. ${ }^{16}$ In particular, laughter is believed to reduce the impact of stress on daily life, ${ }^{16}$ and give a positive energy when individuals try to cope with traumatic events. ${ }^{17}$ A study of humor from Martin \& Lefcourt, ${ }^{18}$ featured an interesting term known as coping humor. Coping humor is different from situational humor response and sense of humor that do not focus on stressful experiences. Coping humor acts as a cognitive appraisal strategy, ${ }^{19}$ it sees the extent to which individuals use humor (present situation) in stressful situations or events (stressful experiences). By looking at the context of this study, the coping humor variable can show the level (quality) of individuals' use of humor during the implementation of the COVID-19 social distancing agenda.

Besides coping humor, the authors included Internal Health Locus of Control (Internal HLoC) which aimed to see how individuals engage themselves (believing that they have control) to establish healthy behavior. The implications of locus of control in health are certainly not new. Previous studies stated in Jacobs-Lawson, Weddell, and Webb's study have found many correlations between locus of control with health outcomes, demographic variables, and many other psychological variables. ${ }^{20}$ Individuals with an internal locus of control tend to be more resistant to psychological pressure and depression. ${ }^{21}$ It is interesting to know the dynamics of Internal HLoC effectiveness amid a pandemic situation, especially for authors. In this study, the authors also examined the effect of humor content: Humor NonCOVID Effect/HNCE (level of entertainment from humor contents on social media unrelated to COVID-19 problems) and Humor COVID Effect/HCE (level of entertainment from humor contents on social media related to COVID-19 issues). During this pandemic, memes and jokes about the coronavirus have spread massively on the internet. Emphasizing the social distancing context, the purpose of this study was to answer the question, "Do coping humor and Internal HLoC can predict social dysfunction and anxiety \& depression due to the implementation of social distancing?". Therefore, the study objective was to find out the predictive effect of coping humor and Internal HLoC on social dysfunction and anxiety \& depression in the implementation of social distancing, as well as the effect of humor content on coping humor.

\section{Method}

The data collection in this study was carried out through a Google Form (study questionnaire link) spread on social media, starting from April 8 to April 15, 2020. The sample size estimation was based on the inverse square root method, which suggested using a minimum of 160 participants when using a Partial Least SquareStructural Equation Modeling (PLS-SEM).22 The total sample in this study was 243 social media users like Instagram, Facebook, Twitter, TikTok, WhatsApp, and YouTube (age 16-64 years, $\mathrm{M}_{\text {age }}=27.9 \mathrm{SD}_{\text {age }}=8.477$; Male $=70$, Female $=173$ ), meaning that the minimum sampling has been fulfilled. All of the scales used were translated into Bahasa Indonesia and then translated back into English to harmonize. Some items have been adjusted so that participants could understand better without reducing the true meaning of the scale (concept and semantic equivalent).

The authors modified the SFQ scale, ${ }^{23}$ to describe a person's social functions (good or bad) over the past two weeks by randomizing the item number and applying a reflective format to measure seven areas; work and homework, finances, social contacts, relationships with family, sexual activity, isolation, and me time. The SFQ is a powerful short instrument and serves to assess social functions in various situations. Then, the authors adapted the Patient Health Questionnaire (PHQ)-4 scale, ${ }^{24}$ a combination of the PHQ-2 and Generalized Anxiety Disorder (GAD)-2 scales. PHQ-4 scale was used to measure the anxiety \& depression levels in the last two weeks. Coping Humor scale, ${ }^{18}$ was also distributed to see how often individuals use humor to cope with stressful experiences during social distancing.

On the other hand, the HLoC scale, ${ }^{21}$ was applied to calculate participants' internal locus of control. Last but not least, HNCE and HCE were constructed by authors to specify the effect of humor content on participants. The HNCE and HCE were composed of one item; as for HNCE, "How much are you entertained by funny contents that are not related to the COVID-19 issues on social media?". For HCE, "How much are you entertained by funny contents that are related to the COVID-19 issues on social media?". Both of which have a response ranging of five choices $(1=$ never feel entertained; 5 = very often feel entertained).

The demographic categorization in this study was sex which consisted of female and male, education which consisted of Diploma III and Bachelor Degree up to Doctoral Degree, and marital status, which consisted of single, married, and widow/widower. As for the anxiety $\&$ depression variable, the categorization was based on related journals, ${ }^{24}$ ranging from minimal, mild, 
moderate, and severe. As for the variables of social dysfunction, coping humor, Internal HLoC, humor content (HNCE and HCE), the authors determined three categories (low, moderate, and high). The variable categorization follows the calculations and guidelines that have been applied. ${ }^{25}$

The authors used a Partial Least Square-Structural Equation Modeling (PLS-SEM) approach through SmartPLS software (v.3.2.8 Single-User Licenses) to analyze the relationship between variables. ${ }^{26}$ In addition to the data categorization values obtained through Microsoft Excel, all variables in this study were also analyzed using SmartPLS software. As for the descriptive analysis in the worksheet, the Validity and Reliability Tests were conducted through PLS algorithm calculation by eliminating several items (coping humor $(\mathrm{CH}) 1, \mathrm{CH} 4$, CH5, locus of control (LOC)5, LOC6, LOC7) based on the outer loading values before direct and indirect testing (presented in Figure 1 and Table 1). The direct and indirect effects (mediation) were obtained through bootstrapping analysis (presented by Figure 2, Table 2, and Table 3 ). Besides simultaneously analyzing constructs formed with reflective and formative indicators, PLS can estimate large/complex models with various construct latent variables and indicators. ${ }^{27}$

\section{Results}

A descriptive analysis and data categorization were performed (Table 1) before the PLS algorithm was conducted to overview of participants' characteristics and the tendency of subject scores in general. Table 1 points out that the majority of the participants were females (71.2\%), have Diploma IV/Bachelor Degree
$(64.2 \%)$, and single/not married $(69.1 \%)$. It is shown that $17.7 \%$ of them have a high level of social dysfunction while the other $67.9 \%$ have a moderate level. The participants have a mild $(44.9 \%)$, moderate $(7.4 \%)$, and severe $(2.1 \%)$ level of anxiety \& depression. It is also

Table 1. Descriptive Analysis and Data Categorization $(n=243)$

\begin{tabular}{|c|c|c|c|}
\hline Variable & Category & $\mathbf{n}$ & $\%$ \\
\hline \multirow[t]{2}{*}{ Gender } & Female & 173 & 71.2 \\
\hline & Male & 70 & 28.8 \\
\hline \multirow[t]{6}{*}{ Education } & High school/vocational & & \\
\hline & high school & 19 & 7.8 \\
\hline & D3/associate degree & 21 & 8.6 \\
\hline & D4/bachelor & 156 & 64.2 \\
\hline & Master & 44 & 18.1 \\
\hline & Doctoral & 3 & 1.2 \\
\hline \multirow[t]{3}{*}{ Marriage status } & Single/not married & 168 & 69.1 \\
\hline & Have marriage & 70 & 28.8 \\
\hline & Widow/widower & 5 & 2.1 \\
\hline Anxiety \& depression & None-minimal & 111 & 45.7 \\
\hline \multirow[t]{3}{*}{$($ Mean $=3.02 ; \mathrm{SD}=2.047)$} & Mild & 109 & 44.9 \\
\hline & Moderate & 18 & 7.4 \\
\hline & Severe & 5 & 2.1 \\
\hline Social dysfunction & High & 43 & 17.7 \\
\hline \multirow[t]{2}{*}{$($ Mean $=6.08 ; \mathrm{SD}=3.498)$} & Moderate & 165 & 67.9 \\
\hline & Low & 35 & 14.4 \\
\hline Coping humor & High & 42 & 17.3 \\
\hline \multirow[t]{2}{*}{$($ Mean $=24.17 ; \mathrm{SD}=4.521)$} & Moderate & 160 & 65.8 \\
\hline & Low & 41 & 16.9 \\
\hline Internal health locus of control & High & 42 & 17.3 \\
\hline \multirow[t]{2}{*}{$($ Mean $=33.73 ;$ SD = 6.777 $)$} & Moderate & 163 & 67.1 \\
\hline & Low & 38 & 15.6 \\
\hline Feel amused about humor content & High & 69 & 28.4 \\
\hline that related to the COVID-19 issues & Moderate & 137 & 56.4 \\
\hline$($ Mean $=2.82 ; \mathrm{SD}=1.091)$ & Low & 37 & 15.2 \\
\hline Feel amused about humor content & High & 63 & 25.9 \\
\hline not related to the COVID-19 issues & Moderate & 127 & 52.3 \\
\hline$($ Mean $=4.02 ; \mathrm{SD}=0.741)$ & Low & 53 & 21.8 \\
\hline
\end{tabular}

Note: SD: Standard Deviation

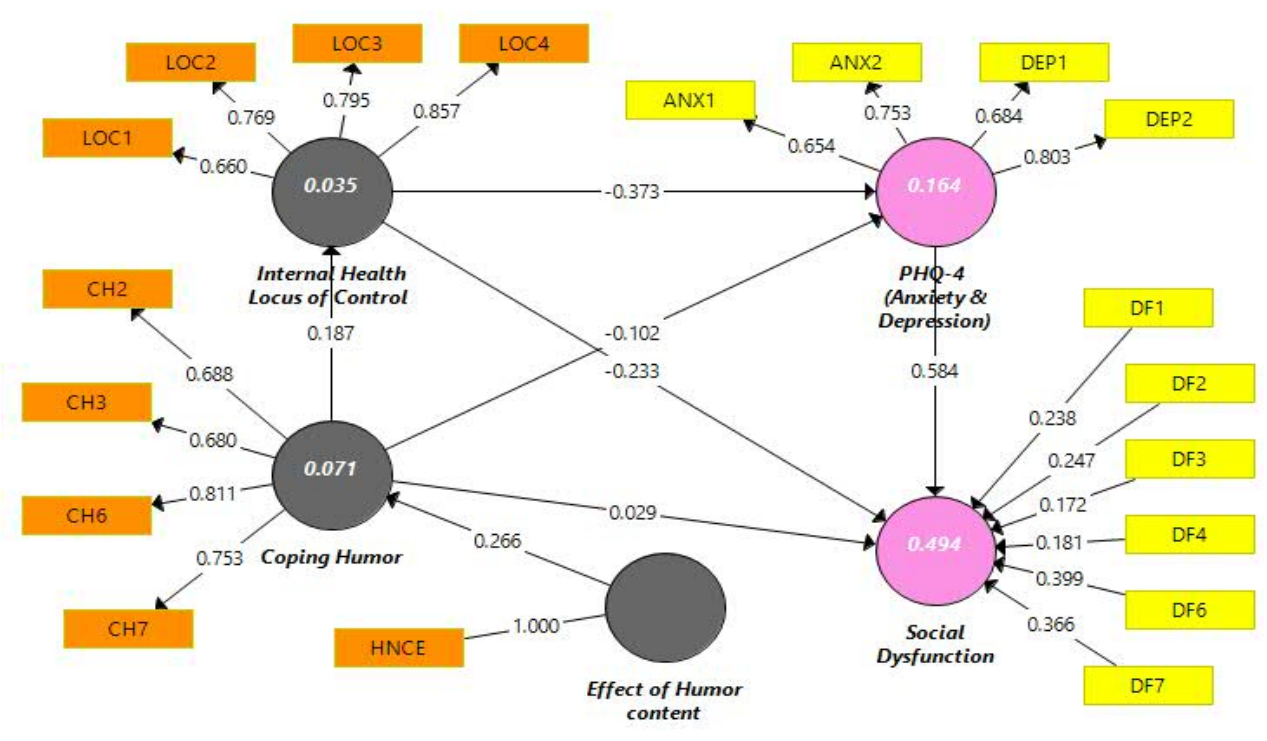

Figure 1. Structural Model (Inner and Outer Model, Path Coefficients) 
Table 2. Validity and Reliability Test (Inner and Outer Model)

\begin{tabular}{|c|c|c|c|c|c|c|}
\hline Construct & Items & Scale & Loadings/t-value Weights & Cronbach's alpha & CR/VIF & AVE \\
\hline \multirow[t]{6}{*}{ Social dysfunction } & DF1 & Formative & 3.320 & - & 1.149 & - \\
\hline & DF2 & & 2.959 & & 1.147 & \\
\hline & DF3 & & 2.176 & & 1.364 & \\
\hline & DF4 & & 2.635 & & 1.112 & \\
\hline & DF6 & & 5.223 & & 1.249 & \\
\hline & DF7 & & 4.349 & & 1.377 & \\
\hline \multirow[t]{4}{*}{ Anxiety \& depression } & ANX1 & Reflective & 0.654 & 0.702 & 0.816 & 0.527 \\
\hline & ANX2 & & 0.753 & & & \\
\hline & DEP1 & & 0.684 & & & \\
\hline & DEP2 & & 0.803 & & & \\
\hline \multirow[t]{4}{*}{ Coping humor } & $\mathrm{CH} 2$ & Reflective & 0.688 & 0.725 & 0.824 & 0.541 \\
\hline & $\mathrm{CH} 3$ & & 0.680 & & & \\
\hline & $\mathrm{CH} 6$ & & 0.811 & & & \\
\hline & $\mathrm{CH} 7$ & & 0.753 & & & \\
\hline \multirow[t]{4}{*}{ Internal health locus of control } & LOC1 & Reflective & 0.660 & 0.785 & 0.855 & 0.598 \\
\hline & LOC2 & & 0.769 & & & \\
\hline & LOC3 & & 0.795 & & & \\
\hline & LOC4 & & 0.857 & & & \\
\hline Effect of humor content & HNCE & Formative & 1.000 & - & 1.000 & - \\
\hline
\end{tabular}

Notes: CR: Composite Reliability; VIF: Collinearity Statistics; AVE: Average Variance Extracted; t-value>1.96; DF1, DF2, DF3, DF4, DF6, DF7: Items of Social Dysfunction; ANX1, ANX2, DEP1, DEP2; Items of Anxiety \& Depression; CH2, CH3, CH6, CH7; Items of Coping Humor; LOC1, LOC2, LOC3, LOC4; Items of Internal HloC; HNCE; Humor Content Contents that are not related to COVID-19 issues

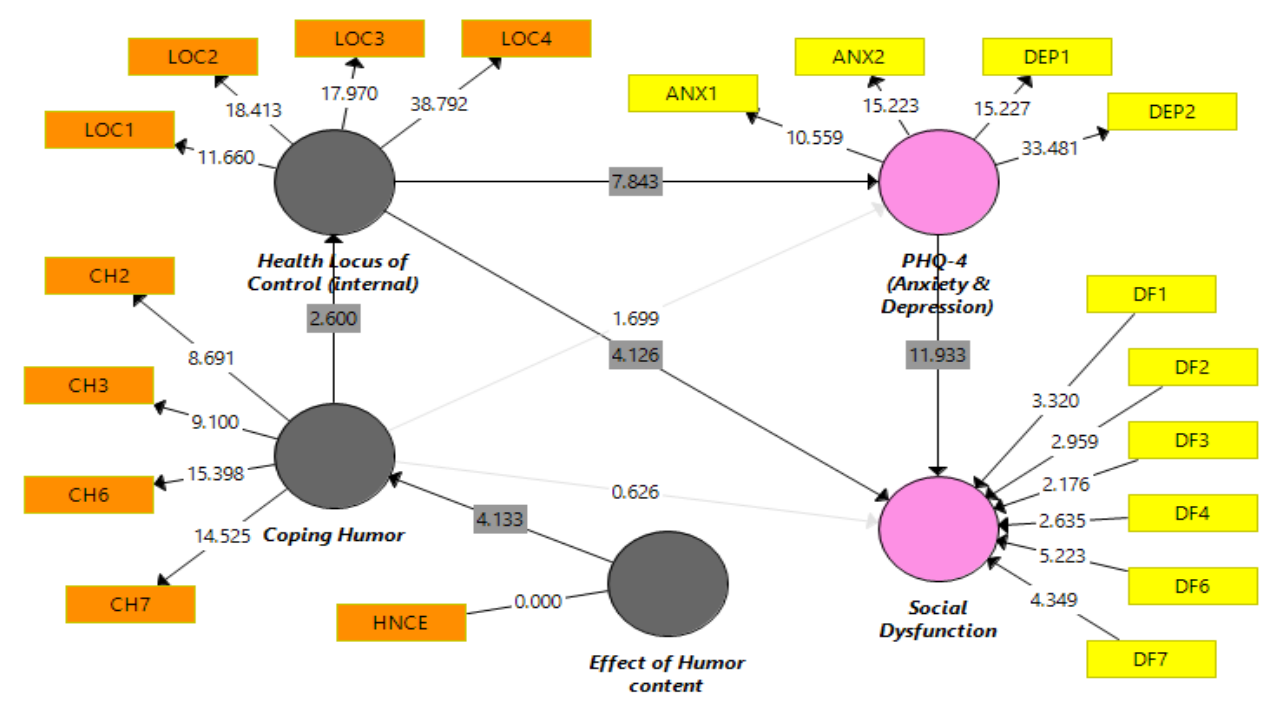

Figure 2. Structural Model (Inner and Outer Model, t-values)

revealed that $17.3 \%$ of them have high coping humor and Internal HLoC. In terms of humor content, 28.4\% of the participants were highly entertained with funny content related to the COVID-19 issues. In comparison, the other $25.9 \%$ were entertained with funny content unrelated to the COVID-19 issues. Figure 1 and Table 2 below show a series of variables involved in this study and have been tested internally and externally.

The reflective scale was evaluated based on the value of AVE ( $>0.5)$, outer loadings ( $>0.6)$, Cronbach's alpha $(>0.6)$, and composite reliability $(>0.7)$. The item with an outer loading value of $<0.6(\mathrm{CH} 1, \mathrm{CH} 4, \mathrm{CH} 5, \mathrm{LOC} 5$, LOC6, LOC7) must be eliminated by the model before direct and indirect tests. Table 1 illustrates that the overall reflective scale has met the convergent validity requirements. The discriminant validity conditions, which were set based on Fornell-Larcker criteria and cross-loading values, also have been fulfilled. On the one hand, the formative scale 28 was assessed based on outer weight bootstrap value ( $\mathrm{p}$-value $<0.05$ ), where the calculation results made item DF5, DF8, and HCE (pvalue $>0.05$ ) eliminated from the model. Figure 2 shows 
Table 3. Direct Effect

\begin{tabular}{lccrrr}
\hline Variable Relationship & Std. Beta & Std. Error & t-value & p-value & $\mathbf{f}^{\mathbf{2}}$ \\
\hline Anxiety \& depression -> Social dysfunction & 0.584 & 0.049 & 11.933 & $0.000^{* * * *}$ & 0.563 \\
Internal HLoC - S Social dysfunction & -0.233 & 0.056 & 4.126 & $0.000^{* * * *}$ & 0.089 \\
Internal HLoC - Anxiety \& depression & -0.373 & 0.048 & 7.843 & $0.000^{* * * *}$ & 0.161 \\
Coping humor - A Anxiety \& depression & -0102 & 0.060 & 1.699 & 0.089 & 0.012 \\
Coping humor - > Social dysfunction & 0.029 & 0.047 & 0.626 & 0.531 & 0.002 \\
Coping humor - Internal HLoC & 0.187 & 0.072 & 2.600 & $0.009^{* * * *}$ & 0.036 \\
Humor content -> Coping humor & 0.266 & 0.064 & 4.133 & $0.000^{* * * *}$ & 0.076 \\
\hline
\end{tabular}

Notes: **"p-value $<0.01,{ }^{*}$ p-value $<0.05 ; \mathrm{f}^{2}$ : Effect Size; HLoC: Health Locus of Control

Table 4. Indirect Effect (Mediation)

\begin{tabular}{lcccc}
\hline Variable Relationship & Std. Beta & Std. Error & t-value & p-value \\
\hline Coping humor - Internal HLoC -> Social dysfunction & -0.144 & 0.050 & 2.859 & $0.004^{* * *}$ \\
Coping humor - Internal HLoC - A Anxiety \& depression & -0.070 & 0.029 & 2.424 & $0.015^{*}$ \\
Humor content - C Coping humor -> Internal HLoC & 0.050 & 0.024 & 2.076 & $0.038^{*}$ \\
Humor content -> Coping humor -> Anxiety \& depression & -0.046 & 0.021 & 2.208 & $0.027^{*}$ \\
Internal HLoC -> Anxiety \& depression -> Social dysfunction & -0.218 & 0.035 & 6.225 & $0.000^{* * *}$ \\
\hline
\end{tabular}

Notes: *"p-value $<0.01$, *p-value $<0.05$; HLoC: Health Locus of Control

an image of the final bootstrap result (5,000 subsamples, CI Method: Bias-Corrected and Accelerated Bootstrap), and blindfold calculations.

Table 3 and Figure 2 indicates anxiety \& depression $(\beta=0.584, \mathrm{M}=0.591,95 \% \mathrm{CI} \mathrm{BCa}=0.473 ; 0.666$, $\mathrm{t}-$ value $=11.93, \mathrm{p}$-value $\left.<0.01, \mathrm{f}^{2}=0.563\right)$ and Internal HLoC ( $\beta=-0.233, \mathrm{M}=-0.233,95 \% \mathrm{CI} \mathrm{BCa}=-0.336$; $0.113, \mathrm{t}$-value $=4.126, \mathrm{p}$-value $<0.01, \mathrm{f}^{2}=0.089$ ) predicts social dysfunction $(\mathrm{R} 2=0.494)$. Internal HLoC predicts anxiety \& depression $(\beta=-0.373, \mathrm{M}=-0.379,95 \% \mathrm{CI}$ $\mathrm{BCa}=-0.457 ;-0.267$, t-value $=7.84$, p-value $<0.01, \mathrm{R} 2=$ $\left.0.164, \mathrm{f}^{2}=0.161\right)$. Coping humor predicts Internal HLoC $(\beta=0.187, \mathrm{M}=0.198,95 \%$ CI $\mathrm{BCa}=0.025$; $0.313, \mathrm{t}$-value $=2.60, \mathrm{p}$-value $<0.01, \mathrm{R} 2=0.035, \mathrm{f}^{2}=$ $0.036)$. Humor content predicts coping humor $(\beta=$ $0.266, \mathrm{M}=0.271,95 \% \mathrm{CI} \mathrm{BCa}=0.124 ; 0.380$, $\mathrm{t}$-value $=$ 4.13, $\mathrm{p}$-value $\left.<0.01, \mathrm{R} 2=0.071, \mathrm{f}^{2}=0.076\right)$.

Table 4 and Figure 2 indicate that coping humor predicts social dysfunction $(\beta=-0.144, \mathrm{M}=-0.153,95 \%$ CI $\mathrm{BCa}=-0.231 ;-0.031, \mathrm{t}$-value $=2.85, \mathrm{p}$-value $<0.01)$ and anxiety $\&$ depression $(\beta=-0.070, \mathrm{M}=-0.075,95 \%$ $\mathrm{CI} \mathrm{BCa}=-0.123 ;-0.012, \mathrm{t}$-value $=2.42, \mathrm{p}$-value $<0.05$ ) through Internal HLoC (mediator variable). Humor content predicts Internal HLoC $(\beta=0.050, \mathrm{M}=0.054$, $95 \%$ CI $\mathrm{BCa}=0.009 ; 0.100, \mathrm{t}$-value $=2.07, \mathrm{p}-$ value $<0.05)$ and anxiety $\&$ depression $(\beta=-0.046, \mathrm{M}=-$ $0.048,95 \%$ CI BC a $=-0.089 ;-0.009$, t-value $=2.20$, $\mathrm{p}-$ value $<0.05)$ through coping humor. Internal HLoC predicts social dysfunction $(\beta=-0.218, M=-0.224,95 \%$ $\mathrm{CI} \mathrm{BCa}=-0.283 ;-0.148$, $\mathrm{t}$-value $=6.22$, $\mathrm{p}$-value $<0.01)$.

\section{Discussion}

Based on Table 1, it is known that many participants of this study have experienced social function problems, anxiety, or depression. Previous studies showed that anxiety and depression have a negative impact on social function. ${ }^{8,9}$ Likewise, the analysis results (see Table 3) strengthen the assumption that anxiety and depression can reduce people's social function (work and homework, finances, social contacts, sexual activity, sense of belonging) during the implementation of social/physical distancing program. In this section, it is necessary to review that anxiety and depression can grow sequentially and even simultaneously on a subject. The symptoms can also be said to overlap like two sides of a coin. However, the difference in question can be seen from the measurement items. Anxiety accentuates the feeling of "nervous, anxious, or on edge," while depression features the feeling of "sad, depressed, or hopeless." The most striking differences are described by Glasofer, ${ }^{29}$ based on a mental marker (symptoms or expressions of the conditions). It is explained that suicidal tendency in anxiety is still limited to the fear of death, whereas, in mild to severe depression, suicidal thoughts will appear to be more specific. From there, it can be said that the impact of depression will be much riskier on social function compared to anxiety.

Concerning humor, the results of this study (see Table 3 and Table 4) support all arguments from every person who suggests having some humor during the implementation of social distancing. ${ }^{30,31}$ This finding is also in line with results from other studies in different situations and conditions. ${ }^{32-35}$ Based on the results of the analysis in this study, coping humor is known to have a direct posi- 
tive effect on the Internal HLoC variable and an indirect negative effect on social dysfunction and anxiety \& depression. This condition indicates that collaborating those two variables can positively impact people's health during difficult situations (e.g., the COVID-19 pandemic). However, it should be emphasized that the effect size found in this study is relatively small. Referring to Fessell, $1570 \%$ of humor occurs spontaneously in everyday life. This result is in line with the unique concept of coping humor that happens in the current situation. It is suitable for people to focus on building positive emotions in the current situation rather than feeling sad to think about what happened in the past or being excessively worried about something that has not happened in the future. Some simple things can be done to improve the quality of humor, such as listening to favorite songs, calling friends who are good at making jokes, especially when difficult situations happen, or just enjoying comedy television shows like standup comedy. Some studies have proved that the strategies above are effective in reducing anxiety and increasing positive emotions. ${ }^{13,36}$

Humor content (HNCE only) is validated (see Table 3 and Table 4) to predict coping humor and Internal HLoC as well as anxiety \& depression (indirect effect). It signifies that humor content on social media (unrelated to the COVID-19) can positively impact coping humor; the more entertained the individual, the higher the coping humor is. This condition eventually will help to decrease social dysfunction and anxiety \& depression. On the other hand, humor content can also predict the positive impact of Internal HLoC on someone's well-being. Previous studies stated in Nick's study have linked laughter to the production of endorphins that can improve mood and reduce stress, increasing disease resistance. ${ }^{37}$ Whereas, please understand and note that even though many studies have proved the positive effect of humor in various contexts, it is still suggested to pay attention to the sensitivity when using humor. Speaking of the concept of humor style, not all types of humor can function well in a pandemic situation. As revealed by Peter McGraw from Humor Research Lab, 37 the authors also advise enjoying and using friendly humor.

Internal HLoC is directly and persistently capable (see Table 3) to predict social dysfunction and anxiety \& depression. The effectiveness of Internal HLoC in the pandemic situation has been demonstrated in this study. Other variables have been tested in other conditions, such as social loafing, ${ }^{38}$ and collective action. ${ }^{39}$ In the field of health, previous studies stated in Kesavayuth, Poyago-Theotoky, and Zikos showed that men and women with Internal HLoC tend to have better self-assessed physical and mental health. They rely less on preventive and curative medical care. ${ }^{21}$ In addition, those with Internal HLoC tend to be less prone to psychological distress and depression. ${ }^{21}$ Jacobs-Lawson, et al., ${ }^{20}$ said that education level as well as self-assessed and self-efficacy health could predict the Internal HLoC. Locus of control is the core dimension of self-evaluation along with neuroticism, self-efficacy, and self-esteem. ${ }^{40}$ In the context of social distancing, individuals with high Internal HLoC will depend more on their inner spirit. They believe that what happens to themselves is a consequence of their actions and efforts.

On the contrary, individuals with high External HLoC will depend more on external factors (e.g., fate, luck, or intervention from others). This result does not mean that External HLoC should be ruled out. A combination of Internal HLoC and External HLoC is possible. This is expected to give more effective and efficient results precisely. The study conducted by April, Dharani, and Peters, ${ }^{41}$ showed that an individual's maximum level of happiness could be achieved with a balanced locus of control that is the combination of two controls (internal and external) known as the "Bi-Locals" type. Rotter mentioned that internality and externality are a continuum, not a typology. ${ }^{42}$ Therefore, the authors of this study argue that conditions and situations should be considered in every locus of control study.

This study is expected to contribute to literature studies related to social dysfunction, anxiety, depression, coping humor, Internal HLoC, and humor contents on social media, particularly regarding implementing a social distancing agenda during the COVID-19 pandemic. In addition to the scientific contribution, this study can be used as a reference for the preparation of social distancing programs such as the socialization to use appropriate humor as a coping strategy in difficult situations or to conduct training to strengthen Internal HLoC in the health sector. Further researches must pay attention to the limitations of the study. For example, this study was conducted only at the beginning of social distancing implementation.

The data collected did not cover until the end of the period and only measured what participants felt in the last two weeks. The effect size also needs to be considered because the effect of coping humor and humor content is relatively small. This study showed that only anxiety \& depression have a significant impact on social dysfunction. Internal HLoC has a relatively small effect on social dysfunction but is moderate on anxiety \& depression. This indicates that other causative variables need to be involved. It also may be caused by the variability of data. Besides that, the social dysfunction scale in this study only measured five areas. Two items that measure "relationships with family" and "me time" were eliminated by the PLS model. Overall, the authors encourage further researchers to pay more attention to the procedures used, such as the measuring instruments, de- 
mographic variables, statistical power, and other locations/regions.

\section{Conclusion}

From the results, it can be concluded that anxiety \& depression directly predict social dysfunction. Coping humor directly predicts Internal HLoC and indirectly predicts social dysfunction and anxiety \& depression. Humor content (only humor content on social media unrelated to the COVID-19 issues) directly predicts coping humor and indirectly predicts Internal HLoC and anxiety \& depression. Moreover, this study reveals that Internal HLoC directly predicts social dysfunction and anxiety \& depression. It means that the higher the anxiety \& depression, the higher the social dysfunction would be. Increasing the Internal HLoC and higher coping humor can also decrease social dysfunction and anxiety \& depression. Humor content unrelated to the COVID-19 issues can increase the level of coping humor and thus lower the level of anxiety \& depression. To sum up, this study proves that Internal HLoC can decrease social dysfunction and anxiety \& depression levels.

\begin{abstract}
Abbreviations
COVID-19: coronavirus disease 2019; WHO: World Health Organization; HNCE: Humor Non-Covid Effect; HCE: Humor Covid Effect; SFQ: Social Function Questionnaire; PHQ: Patient Health Questionnaire; GAD: Generalized Anxiety Disorders; CH: Coping Humor; SD: Standard Deviation; M: Mean; PLS-SEM: Partial Least Square-Structural Equation Modeling; CI Bca: Confidence Interval Bias Corrected and Accelerated; VIF: Collinearity Statistics; AVE: Average Variance Extracted; CR: Composite Reliability; HLoC: Health Locus of Control.
\end{abstract}

\section{Ethics Approval and Consent to Participate}

Ethical approval was obtained from the local hospital (No. 239/KomEtik/Int/VI/2019).

\section{Competing Interest}

The authors declare that there are no significant competing financial, professional, or personal interests that were likely to have affected the performance or presentation of the work described in this manuscript.

\section{Availability of Data and Materials}

Data and all related materials are available to all authors. Please get in touch with the correspondence if data is required.

\section{Authors' Contribution}

MAS proposed research topic. Overall, all of the authors (MAS, Z, HRA, AZF) are involved and contribute to every step of the process of drafting the manuscript.

\section{Acknowledgment}

The authors would like to thank all participants who helped to spread the research questionnaire, especially the colleagues from Intellectual Freedom (Ruang Ide) and Halo Jiwa Indonesia.

\section{References}

1. Kartono DT. Pentingnya solidaritas untuk mendukung social distancing. Inews; 2020.

2. Stawicki SP, Jeanmonod R, Miller AC, Paladino L, Gaieski DF, Yaffee AQ, et al. The 2019-2020 novel coronavirus pandemic: a joint American college of academic international medicine-world academic council of emergency medicine multidisciplinary COVID-19 working group consensus paper. Journal of Global Infectious Diseases. 2020; 12 (2): 47-3.

3. Sibley C, Greaves L, Satherley N, Wilson MS, Overall N, Lee C, et al. Effects of the COVID-19 pandemic and nationwide lockdown on trust, attitudes towards government, and well-being. American Psychologist. 2020; 75 (5): 618-0.

4. Blustein DL, Duffy R, Ferreira JA, Cohen-Scali V, Cinamon RG, Allan BA. Unemployment in the time of COVID-19: a research agenda. Journal of Vocational Behavior. 2020; 119: 1-4.

5. Restubog SLD, Ocampo ACG, Wang L. Taking control amidst the chaos: emotion regulation during the COVID-19 pandemic. Journal of Vocational Behavior. 2020; 119: 1-5.

6. Rudolph CW, Allan B, Clark M, Hertel G, Hirschi A, Kunze F, et al. Pandemics: implications for research and practice in industrial and organizational psychology; 2020.

7. Zacher $\mathrm{H}$, Rudolph $\mathrm{CW}$. Individual differences and changes in subjective well-being during the early stages of the COVID-19 pandemic. American Psychologist. 2020; 1-13.

8. Kupferberg A, Bicks L, Hasler G. Social functioning in major depressive disorder. Neuroscience \& Biobehavioral Reviews. 2016; 69: 313-2.

9. Cox KL. The relationship between social functioning and anxiety symptoms in preschoolers with autism. [Thesis]. University of South Carolina, Columbia; 2020.

10. Polimeni JO, Campbell DW, Gill D, Sawatzky BL, Reiss JP. Diminished humour perception in schizophrenia: relationship to social and cognitive functioning. Journal of Psychiatric Research. 2010; 44 (7): 434-0.

11. Dyck KT, Holtzman S. Understanding humor styles and well-being: the importance of social relationships and gender. Personality and Individual Differences. 2013; 55 (1): 53-8.

12. Stanley JT, Lohani M, Isaacowitz DM. Age-related differences in judgments of inappropriate behavior are related to humor style preferences. Psychology and Aging. 2014; 29 (3): 528-1.

13. Ruch W, McGhee PE. Humor intervention programs. Eds. Hoboken: Wiley-Blackwell; 2014.

14. Martin RA, Ford T. The psychology of humor: an integrative approach. 1st ed. Landon Wall: Academic press; 2018.

15. Fessell D. Laughter leaves me lighter: coping with COVID-19. Jama. 2020; 323 (24): 2476-7.

16. Nusbaum EC, Silvia PJ, Beaty RE. Ha ha? Assessing individual differences in humor production ability. Psychology of Aesthetics, Creativity, and the Arts. 2017; 11 (2): 231-1.

17. Kuiper NA. Humor and resiliency: towards a process model of coping 
and growth. Europe's Journal of Psychology. 2012; 8 (3): 475-1.

18. Sun P, Chen JJ, Jiang H. Coping humor as a mediator between emotional intelligence and job satisfaction. Journal of Personnel Psychology. 2017; 16: 155-9.

19. Martin RA, Ford TE. The psychology of humor: an integrative approach. 2nd Edition. Elsevier: Academic Press; 2018.

20. Jacobs-Lawson JM, Waddell EL, Webb AK. Predictors of health locus of control in older adults. Current Psychology. 2011; 30 (2): 173.

21. Kesavayuth D, Poyago-Theotoky J, Zikos V. Locus of control, health and healthcare utilization. Economic Modelling. 2020; 86: 227-8.

22. Kock N, Hadaya P. Minimum sample size estimation in PLS - SEM: the inverse square root and gamma - exponential methods. Information Systems Journal. 2018; 28 (1): 227-1.

23. Tsai J, Harpaz-Rotem I, Pietrzak, Southwick SM. The role of coping, resilience, and social support in mediating the relation between PTSD and social functioning in veterans returning from Iraq and Afghanistan. Psychiatry: Interpersonal \& Biological Processes. 2012; 75 (2): 135-49.

24. Kroenke K, Baye F, Lourens SG. Comparative validity and responsiveness of PHQ-ADS and other composite anxiety-depression measures. Journal of affective disorders. 2019; 246: 437-43.

25. Azwar S. Penyusunan skala psikologi. 2nd Edition. Yogyakarta: Pustaka belajar; 2015.

26. Ringle CM, Wende S, Becker JM. SmartPLS 3. Smartpls; 2015.

27. Hair JF, Hult GTM, Ringle CM, Sarstedt M. 2nd ed. A primer on partial least squares structural equation modeling (PLS-SEM). Thousand Oaks: Sage useful; 2017.

28. Hair JF, Risher JJ, Sarstedt M, Ringle CM. When to use and how to report the results of PLS-SEM. European Business Review. 2019; 31 (1): $2-24$.

29. Glasofer. Overlapping and distinguishing features of anxiety and depression. Verywell mind; 2020.
30. Fadhilah UM, Dwinanda R. Tertawa di tengah bekapan pandemi COVID-19. Republika; 2020.

31. Rahmawati Y, Nofiana F. Humor saat pandemi corona, peneliti: tawa dimasa sulit adalah katarsis. Suara; 2020.

32. Ford T, McCreight K, Richardson K. Affective style, humor styles and happiness. Europe's Journal Of Psychology. 2014; 10 (3): 451-3.

33. Sun P, Chen JJ, Jiang H. Coping humor as a mediator between emotional intelligence and job satisfaction. Journal of Personnel Psychology. 2017; 16: 155-9.

34. Kayiş AR, Satici SA. The mediating role of forgiveness in the relationship between coping humor and mental well-being. Kastamonu Education Journal. 2019; 27 (4): 1495-4.

35. Morgan J, Smith R, Singh, A. Exploring the role of humor in the management of existential anxiety. Humor. 2019; 32 (3): 433-8.

36. Szabo A. The acute effects of humour and exercise on mood and anxiety. Journal of Leisure Research. 2017; 35 (2): 152-2.

37. Nick S. In the midst of a pandemic, humor researcher says make laughter infectious. Kunc; 2020.

38. Sumantri MA, Pratiwi I. Locus of control: upaya untuk menurunkan social loafing. Jurnal Ilmiah Psikologi Terapan. 2020; 8 (1): 8

39. Fukuzawa A, Inamasu K. Relationship between the internal locus of control and collective action: a comparison of East Asian and Western Countries. Asian Journal of Social Psychology. 2020; 23 (3): 349-9.

40. Srivastava A, Locke EA, Judge TA, Adams JW. Core self-evaluations as causes of satisfaction: the mediating role of seeking task complexity. Journal of Vocational Behavior. 2010; 77 (2): 255-5.

41. April KA, Dharani B, Peters K. Impact of locus of control expectancy on level of well-being. 2012; 4 (2): 124-7.

42. Mohammad A, Paul S. Comparative study on emotional intelligence and locus of control among high and low female achievers of volleyball players. International Journal of Physiology, Nutrition and Physical Education. 2019; 4 (1): 1636-8. 